\title{
Penggunaan Metode AHP Pengangkatan Karyawan Tetap Pada PT Prima Top Boga
}

\author{
Saepul Kodir ${ }^{1}$, Nurmalasari ${ }^{2}$, Ani Yoraeni ${ }^{3}$ \\ 1,2,3 Program Studi Sistem Informasi, Universitas Nusa Mandiri \\ Jl. Jatiwaringin Raya No.02 Cipinang Melayu Kecamatan Makasar Jakarta Timur, Indonesia

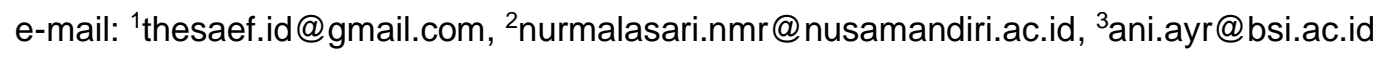

\begin{tabular}{llll}
\hline Informasi Artikel Diterima: 22-02-2021 Direvisi: 07-06-2021 & Disetujui: 06-07-2021 \\
\hline
\end{tabular}

\begin{abstract}
Abstrak
Karyawan merupakan aset penting bagi perusahaan. Tanpa karyawan. Untuk itu, PT Prima Top Boga haruslah tidak salah dalam merekrut karyawannya. Permasalahan yang terjadi pada PT Prima Top Boga yaitu masih belum optimalnya dalam proses perekrutan karyawan tetap dan sering terjadi kesalahan dalam memilih karyawan terbaik untuk direkrut menjadi karyawan tetap. Dalam hal ini penulis menggunakan metode Analytical Hierarchy Process dengan enam kriteria didalamnya sebagai tolak ukur dalam penelitian serta empat alternatif. Pada penelitian ini, penulis membagikan kuesioner kepada tiga responden yang berkompeten pada bidang terkait, kemudian data tersebut diolah dengan menggunakan aplikasi microsoft excel dan aplikasi expert choice. Maka yang berhasil menjadi karyawan tetap adalah Karta Atmaja dengan preferensi sebanyak 0.344 . atau $34 \%$.
\end{abstract}

Kata Kunci: Pengangkatan, Karyawan, Analitycal Hierarchy Process (AHP)

\begin{abstract}
Employees are an important asset to the company. No employees. Therefore, PT Prima Top Boga must not be wrong in recruiting its employees. The problem that occurs at PT Prima Top Boga is still not optimal in the process of hiring permanent employees and there is often a mistake in choosing the best employees to be recruited into permanent employees. In this case the author used the Analytical Hierarchy Process method with six criteria in it as a benchmark in the study as well as four alternatives. In this study, the authors shared questionnaires with three respondents who were competent in related fields, then the data was processed using microsoft excel application and expert choice application. So who managed to become a permanent employee is Karta Atmaja with a preference of 0.344. or 34\%.
\end{abstract}

Keywords: Appointment, Employee, Analitycal Hierarchy Process (AHP)

\section{Pendahuluan}

Karyawan merupakan salah satu aspek yang sangat penting dalam proses pencapaian tujuan pada suatu perusahaan. Tanpa karyawan, sebuah perusahaan tidak akan mampu mencapai keberhasilan meski memiliki peralatan yang berteknologi tinggi. Teknologi tidak dapat mampu berjalan tanpa adanya karyawan yang bekerja dibelakangnya. Maka dari itu peran dan fungsi karyawan amat sangat vital sehingga tidak dapat digantikan oleh sumber daya yang lain. Sebuah perusahaan harus memiliki karyawan yang berkompeten pada bidangnya. Pengelolaan SDM memerlukan standarisasi yang jelas agar dapat memberikan kontribusi yang positif bagi suatu perusahaan atau organisasi(Pratiwi et al., 2018).
Dilihat dari pentingnya karyawan pada perusahaan, maka sepantasnya perusahaan memberikan perhatian yang lebih melalui kebijakan yang diambil serta perlu secara rutin melakukan penilaian atas kinerja para karyawannya.

Penelitian sebelumnya yaitu Umar, Fadlil, dan Yuminah melakukan penelitian mengenai SPK dengan metode AHP untuk penilaian kompetensi soft skill (Umar et al., 2018)

Penelitian lain yaitu SPK pembelian rumah Di kota Tangerang, dengan urutan prioritas adalah lokasi, harga, spesifikasi bangunan, kredibilitas developer dan cara pembayaran. Data penelitiannya diperoleh dari hasil kuisioner responden(Putri \& Mahendra, 2019) 
Dalam penelitian sebelumnya Aji Sasongko yang berjudul pemilihan karyawan baru dengan metode AHP, menjelaskan bahwa proses pembuatan Sistem Pemilihan Karyawan Baru bisa dilakukan dengan menggunakan metode Analytic Hierarchy Process (AHP) dengan bobot dan kriteri yang telah ditentukan oleh PT. Noreen Surya Perdana dimana data tersebut diperoleh dari hasil wawancara kemudian olah oleh sistem sehingga menghasilkan output perangkingan karyawan baru.(Sasongko et al., 2017)

PT Prima Top Boga merupakan perusahaan yang bergerak dalam bidang industri makanan khususnya pastry. Dalam meningkatkan kinerja karyawan PT Prima Top Boga melakukan pemilihan karyawan tetap berdasarkan data absensi dan perilaku selama karyawan tersebut bekerja dalam masa kontrak serta melakukan pengumpulan penilaianpenilaian dari berbagai atasan dari tiap departemen. Tetapi cara tersebut masih belum optimal dalam pelaksanaannya karena masih banyak karyawan yang memiliki kinerja bagus tetapi tidak diangkat menjadi karyawan tetap, sebaliknya karyawan yang memiliki kinerja yang biasa saja tetapi diangkat menjadi karyawan tetap. Setiap tahun PT Prima Top Boga mampu mengangkat karyawan kontraknya hanya maksimal 10 karyawan untuk itu dengan adanya kebutuhan pengangkatan karyawan tetap pada PT Prima Top Boga maka pihak SDM perlu memfilter karyawan kontrak yang ada menjadi karyawan tetap

$$
\text { Untuk mengatasi permasalahan }
$$

tersebut maka diperlukan suatu sistem pendukung keputusan dengan menerapkan suatu metode yang dapat mempermudah dalam pemilihan karyawan tetap yaitu dengan menerapkan metode Analytical Hierarki Proceas (AHP). Sistem Pendukung Keputusan (SPK) merupakan sistem yang dapat memberikan berbagai solusi dari masalah yang semi terstruktur maupun terstruktur, SPK mendukung berbagai level, baik individu mapun juga kelompok. (Fauzi et al., 2020). Sistem pendukung keputusan merupak seperangkat elemen yang digabungkan menjadi satu dengan yang lainnya sehingga saling bekerja sama untuk menghasilkan satu kesatuan untuk pencapaian suatu tujuan bersama. (PHS \& Destiana, 2020) Konsep metode Analytical Hiererchy Process (AHP) merupakan suatu konsep yang sangat sederhana sehingga mudah dipahami, komputasinya efisien dan memiliki kemampuan untuk mengukur kinerja dari berbagai keputusan dalam bentuk matematis yang sederhana. AHP (Analytical Hierarchy Process) adalah teori umum mengenai pengukuran yang digunakan untuk menemukan skala rasio, baik dari perbandingan berpasangan diskrit maupun yang kontinyu(Narti et al., 2019).

Ada juga metode-metode lain yang bisa digunakan dalam melakukan penelitian pengangkatan karyawan tetap diantaranya:

a. Fuzy Multi Attribute Decision Making (FMADM)

Merupakan suatu metode yang digunakan untuk mencari alternative pilihan dari beberapa alternatif dengan berbagai kriteria. (Supriyadi et al., 2019) Inti dari FMADM yaitu menentukan nilai bobot pada setiap atribut, kemudian dilanjutkan dengan proses perankingan yang sudah diberikan. (Fauzi et al., 2020)

b. Simple Addictive Weighting (SAW)

Merupakan salah satu model yang dapat digunakan pada proses pengambilan keputusan dengan penjumlahan terbobot (Agustini \& Ariska, 2019). Berdasarkan namanya, metode SAW dapat didefinisikan sebagai metode pembobotan sederhana atau penjumlahan terbobot pada penyelesaian masalah pada sebuah sistem pendukung keputusan. (Nofriansyah \& Defit, 2017)

c. Weighted Product (WP)

Metode pengambilan keputusan dngan cara perkalian untuk menghubungkan rating atribut, dimana rating setiap atribut harus dipangkatkan terlebih dahulu dengan bobot atribut yang bersangkutan untuk mendapat hasilnya. (Budihartanti et al., 2020)

d. ELECTRE

Metode ini digunakan untuk kondisi alternatif yang tidak sesuai, dengan kriteria dieliminasi sehingga alternatif yang sesuai dapat dihasilkan (Mahmudi et al., 2019)

e. Technique For Order Preference By Similarity To Ideal Solution (TOPSIS)

Adalah suatu metode yang dapat menyelesaikan permasalahan dengan berbagai multi kriteria (Hertyana, 2019)

Dalam permasalahan ini penulis memilih metode Analytical Hierarki Process (AHP) untuk mempermudah dalam pemilihan karyawan tetap yang dibutuhkan oleh PT Prima Top Boga. Dimana AHP ini merupakan suatu proses untuk mengidentifikasi dan memberikan perkiraan interaksi sistem keseluruhan. (Narti, 2017)

\section{Metode Penelitian}

Proses pengumpulan data primer dilakukan dengan menyebarkan kuesioner kepada tiga responden dari departemen HRD PT Prima Top Boga yang hasilnya akan dianalisis menggunakan metode 
pengembangan dari Prof. Thomas L. Saaty yaitu Analytical Hierarchy Process (AHP) Metode Analytical Hierarchy Process ini membantu memecahkan persoalan yang kompleks dengan menstruktur suatu hirarki kriteria, pihak yang berkepentingan, hasil dan dengan menarik berbagai pertimbangan guna mengembangkan bobot atau prioritas(Saputra \& Sudrajat, 2020).

Dalam menyelesaikan permasalahan dengan AHP ada beberapa prinsip yang harus dipahami diantaranya adalah Decomposition (Membuat Hierarki), Comparative Judgment (Penilaian Kriteria dan Alternatif), Syntesis of Priority (Menentukan Prioritas) dan Logical Consistency (Konsistensi Logis)

Prosedur dan Langkah-langkah metode AHP meliputi identifikasi masalah, menentukan prioritas elemen, pertimbangan terhadap perbandingan berpasangan sintesis untuk memperoleh keseluruhan prioritas, konsistensi, hitung $\mathrm{Cl}$ dengan rumus $\mathrm{Cl}=(\lambda$ maks- $n) / n$ dan hitung $\mathrm{CR}$ dengan rumus $\mathrm{CR}=\mathrm{Cl} / \mathrm{RC}$ dan memeriksa konsistensi hierarki. (Iriadi \& Yohana, 2016)

Kuesioner berisi pertanyaan-pertanyaan tentang perbandingan dua elemen atau perbandingan berpasangan (pairwise comparison). Skala yang digunakan yaitu 1-9. Untuk berbagi permasalahan, skala 1 sampai 9 merupakan skala yang terbaik dalam mengkualifikasikan pendapat, yaitu berdasarkan akurasinya berdasarkan nilai Root Mean Square (RMS) dan Median Absolute Deviation (MAD)(Marsono, 2020).

Tabel. I Skala Matriks Perbandingan Berpasangan

\begin{tabular}{lll}
\hline $\begin{array}{l}\text { Integritas } \\
\text { Kepentinga } \\
\mathrm{n}\end{array}$ & Definisi & Penjelasan \\
\hline 1 & & \\
& Elemen yang & Kedua \\
& satu sama elemen \\
pentingnya & menyumban \\
& dibanding & $\mathrm{g}$ sama \\
& dengan yang & besar sama \\
& elemen yang & sifat tersebut \\
& lain (equal & \\
& importance) & \\
3 & Elemen yang & Pengalaman \\
& satu sedikit & menyatakan \\
& lebih penting & sedikit \\
& daripada & memihak \\
& elemen yang pada satu \\
& lain & elemen \\
& (moderate & \\
& more & \\
& importance) & \\
\hline
\end{tabular}

5

\begin{tabular}{|c|c|}
\hline $\begin{array}{l}\text { Elemen yang } \\
\text { satu jenis } \\
\text { lebih penting } \\
\text { dari pada } \\
\text { elemen yang } \\
\text { lain } \\
\text { (essential, } \\
\text { strong more } \\
\text { importance) }\end{array}$ & $\begin{array}{l}\text { Pengalaman } \\
\text { menunjukan } \\
\text { secara kuat } \\
\text { memihak } \\
\text { pada satu } \\
\text { elemen }\end{array}$ \\
\hline $\begin{array}{l}\text { Elemen yang } \\
\text { satu jelas } \\
\text { lebih penting } \\
\text { dari elemen } \\
\text { yang lain } \\
\text { (absolutely } \\
\text { more } \\
\text { importance) }\end{array}$ & $\begin{array}{l}\text { Pengalaman } \\
\text { menunjukan } \\
\text { secara kuat } \\
\text { disukai dan } \\
\text { didominasi } \\
\text { oleh sebuah } \\
\text { elemen } \\
\text { tampak } \\
\text { dalam }\end{array}$ \\
\hline $\begin{array}{l}\text { Elemen yang } \\
\text { satu mutlak } \\
\text { lebih penting } \\
\text { daripada } \\
\text { elemen yang } \\
\text { lain } \\
\text { (demonstrate } \\
\text { dimportance) }\end{array}$ & $\begin{array}{l}\text { Pengalaman } \\
\text { menunjukan } \\
\text { satu elemen } \\
\text { sangat jelas } \\
\text { lebih penting }\end{array}$ \\
\hline $\begin{array}{l}\text { Apabila ragu- } \\
\text { ragu antara } \\
\text { dua nilai yang } \\
\text { berdekatan } \\
\text { (grey area) }\end{array}$ & $\begin{array}{l}\text { Nilai ini } \\
\text { diberikan bila } \\
\text { diperlukan } \\
\text { kompromi }\end{array}$ \\
\hline
\end{tabular}

Sumber: (Diana, 2018)

Dalam penelitian ini terdapat 6 kriteria yang digunakan yaitu pengetahuan, keterampilan, sikap kerja, komunikasi, kehadiran dan kerja sama dan alternatif yang diambil sebanyak 4 karyawan yang terdiri dari Agi Suci Nur Indra, John David Sitohang, Karta Atmaja dan Rizki Abdullah

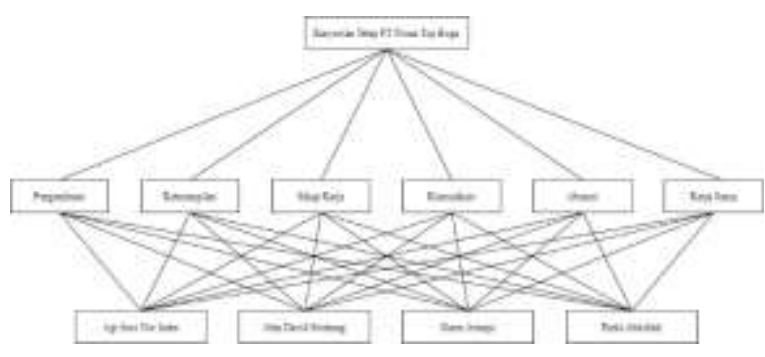

Sumber: Penelitian Penulis

\section{Gambar1. Model Hirarki Calon Karyawan Tetap PT Prima Top Boga}

\section{Hasil dan Pembahasan}

Setelah semua responden sudah mengisi kuesioner kemudian dikumpulkan lalu digabungkan untuk mengetahui hasil dari datadata perbandingan berpasangan yang 
diperoleh. Kemudian dicari satu jawaban ratarata atau Geometric Mean. Untuk mendapatkan nilai rata-rata, masing-masing hasil dari quesioner harus dikalikan satu dama lain kemudian hasil perkalian dipangkatkan dengan $1 / n$ dimana $n$ adalah jumlah partisipan $a w \sqrt[n]{a 1, x a 2, x 3 \ldots x a}$

Berikut ini adalah nilai rata-rata kriteria utama perhitungan matriks perbandingan 3 responden yang sudah direkapitulasi hasilnya. Maka hasil perbandingan dari kriteria utama adalah:

Tabel. 2 Perbandingan Kriteria Utama

\begin{tabular}{cllllll}
\hline $\begin{array}{c}\text { KRITE } \\
\text { RIA }\end{array}$ & $\begin{array}{c}\text { Penge } \\
\text { tahuan }\end{array}$ & $\begin{array}{c}\text { Ketera } \\
\text { mpilan }\end{array}$ & $\begin{array}{c}\text { Sikap } \\
\text { Kerja }\end{array}$ & $\begin{array}{c}\text { Komun } \\
\text { ikasi }\end{array}$ & $\begin{array}{c}\text { Kehadi } \\
\text { ran }\end{array}$ & $\begin{array}{c}\text { Kerjas } \\
\text { ama }\end{array}$ \\
\hline $\begin{array}{c}\text { Penget } \\
\text { ahuan }\end{array}$ & 1.00 & 1.65 & 0.44 & 3.00 & 0.28 & 0.44 \\
$\begin{array}{c}\text { Ketera } \\
\text { mpilan }\end{array}$ & 0.61 & 1.00 & 0.50 & 2.00 & 0.30 & 0.31 \\
$\begin{array}{c}\text { Sikap } \\
\text { Kerja }\end{array}$ & 2.29 & 2.00 & 1.00 & 2.88 & 0.31 & 0.44 \\
$\begin{array}{c}\text { Komun } \\
\text { ikasi }\end{array}$ & 0.33 & 0.50 & 0.55 & 1.00 & 0.20 & 0.27 \\
$\begin{array}{c}\text { Kehadi } \\
\text { ran }\end{array}$ & 3.63 & 3.30 & 3.17 & 4.93 & 1.00 & 1.82 \\
$\begin{array}{c}\text { Kerjas } \\
\text { ama }\end{array}$ & 2.29 & 3.17 & 2.29 & 3.68 & 0.55 & 1.00 \\
Jumlah & 10.15 & 11.63 & 7.95 & 17.50 & 2.65 & 4.28 \\
\hline
\end{tabular}

Sumber: Hasil Penelitian

Selanjutnya setiap unsur-unsur pada tiap kolom dibagi dengan jumlah kolom yang bersangkutan maka akan diperoleh bobot alternatif yang dinormalkan. Kemudian dari masing-masing kriteria tersebut lalu di jumlahkan. Setelah didapat hasil dari penjumlahan maka selanjutnya adalah menentukan nilai rata-rata (Priority Vactor) dengan membagi hasil ratarata dengan jumlah kriteria yakni 6. Maka diperoleh hasil sebagai berikut:

Tabel. 3 Matriks Nilai Eigen Kriteria Utama

\begin{tabular}{|c|c|c|c|c|c|c|c|c|}
\hline \multicolumn{7}{|c|}{ NILAI EIGEN } & \multirow{2}{*}{$\begin{array}{c}\text { Jum } \\
\text { lah }\end{array}$} & \multirow{2}{*}{$\begin{array}{c}\begin{array}{c}\text { Prio } \\
\text { rity }\end{array} \\
\text { Vact } \\
\text { or }\end{array}$} \\
\hline $\begin{array}{l}\text { KRIT } \\
\text { ERIA }\end{array}$ & $\begin{array}{c}\text { Pen } \\
\text { geta } \\
\text { hua } \\
n\end{array}$ & $\begin{array}{c}\text { Kete } \\
\text { ramp } \\
\text { ilan }\end{array}$ & $\begin{array}{c}\text { Sika } \\
p \\
\text { Kerj } \\
a\end{array}$ & $\begin{array}{c}\text { Ko } \\
\text { mun } \\
\text { ikasi }\end{array}$ & $\begin{array}{l}\mathrm{Ke} \\
\text { had } \\
\text { iran }\end{array}$ & $\begin{array}{c}\text { Kerj } \\
\text { asa } \\
\text { ma }\end{array}$ & & \\
\hline $\begin{array}{l}\text { Peng } \\
\text { etah } \\
\text { uan }\end{array}$ & 0.10 & 0.14 & 0.05 & 0.17 & $\begin{array}{l}0.1 \\
0\end{array}$ & $\begin{array}{l}0.1 \\
0\end{array}$ & 0.67 & 0.11 \\
\hline $\begin{array}{l}\text { Kete } \\
\text { ramp } \\
\text { ilan }\end{array}$ & 0.06 & 0.09 & 0.06 & 0.11 & $\begin{array}{l}0.1 \\
1\end{array}$ & $\begin{array}{l}0.0 \\
7\end{array}$ & 0.51 & 0.09 \\
\hline $\begin{array}{c}\text { Sika } \\
p \\
\text { Kerja }\end{array}$ & 0.23 & 0.17 & 0.13 & 0.16 & $\begin{array}{l}0.1 \\
2\end{array}$ & $\begin{array}{l}0.1 \\
0\end{array}$ & 0.91 & 0.15 \\
\hline $\begin{array}{c}\text { Kom } \\
\text { unik } \\
\text { asi }\end{array}$ & 0.03 & 0.04 & 0.07 & 0.06 & $\begin{array}{l}0.0 \\
8\end{array}$ & $\begin{array}{l}0.0 \\
6\end{array}$ & 0.34 & 0.06 \\
\hline $\begin{array}{l}\text { Keha } \\
\text { diran }\end{array}$ & 0.36 & 0.28 & 0.40 & 0.28 & $\begin{array}{l}0.3 \\
8\end{array}$ & $\begin{array}{l}0.4 \\
2\end{array}$ & 2.13 & 0.35 \\
\hline $\begin{array}{l}\text { Kerja } \\
\text { sam } \\
\text { a }\end{array}$ & 0.23 & 0.27 & 0.29 & 0.21 & $\begin{array}{l}0.2 \\
1\end{array}$ & $\begin{array}{l}0.2 \\
3\end{array}$ & 1.44 & 0.24 \\
\hline $\begin{array}{l}\text { Juml } \\
\text { ah }\end{array}$ & 1.00 & 1.00 & 1.00 & 1.00 & $\begin{array}{l}1.0 \\
0\end{array}$ & $\begin{array}{l}1.0 \\
0\end{array}$ & 6.00 & 1.00 \\
\hline
\end{tabular}

Sumber: Hasil Penelitian
Selanjutnya menghitung nilai konsistensi rasio dari matriks perbandingan kriteria utama. Langkah-langkahnya sebagai berikut:

1. Mencari nilai $\mathrm{Cl}$ (Consistency Indeks)

Dalam mencari nilai $\mathrm{Cl}$ (Consistency Indeks) terlebih dahulu kita cari nilai lamda max, yang harus dilakukan adalah mengalikan setiap jumlah nilai kriteria utama dengan hasil setiap rata-rata (Priority Vactor) dari kriteria utama maka hasil yang diperoleh adalah:

$\lambda_{\text {Max }}=6.295$

Karena matriks terdiri dari 6 kriteria maka indeks konsistensi yang diperoleh sebagai berikut:

$\mathrm{Cl}=\frac{\lambda_{\operatorname{Max}}-n}{n-1}=\frac{6.295-6}{6-1}=\frac{(0.295)}{5}=0.059$

2. Menentukan nilai RI

Matriks terdiri dari 6 kriteria maka nilai RI yang di dapat adalah 1.24

3. Menghitung CR (Consistency Rasio)

Jika $n=6, \mathrm{RI}=1.24$ maka:

$C R \frac{C I}{I R}=\frac{0.059}{1.24}=0.048$

Karena CR $<0.100$ maka preferensi responden adalah konsisten.

A. Perhitungan Alternatif Kriteria Pengetahuan

Tabel 4 Perhitungan Alternatif Kriteria Pengetahuan

\begin{tabular}{lllll}
\hline $\begin{array}{l}\text { Pengetahu } \\
\text { an }\end{array}$ & Agi & David & Karta & Rizki \\
\hline Agi & 1.00 & 2.00 & 3.42 & 3.00 \\
David & 0.50 & 1.00 & 4.31 & 2.62 \\
Karta & 0.29 & 0.23 & 1.00 & 0.63 \\
Rizki & 0.33 & 0.38 & 1.59 & 1.00 \\
Jumlah & 2.13 & 3.61 & 10.32 & 7.25 \\
\hline
\end{tabular}

Sumber: Hasil Penelitian

Selanjutnya setiap unsur-unsur pada tiap kolom dibagi dengan jumlah kolom yang bersangkutan maka akan diperoleh bobot alternatif yang dinormalkan. Kemudian dari masing-masing alternatif tersebut lalu di jumlahkan. Setelah didapat hasil dari penjumlahan maka selanjutnya adalah menentukan nilai rata-rata (Priority Vactor) dengan membagi hasil rata-rata dengan jumlah alternatif yakni 4. Maka diperoleh hasil sebagai berikut: 
Tabel 5 Nilai Eigen Alternatif Kriteria Pengetahuan

\begin{tabular}{cccccccc}
\hline & \multicolumn{3}{c}{ NILAI EIGEN } & \multicolumn{3}{c}{$\begin{array}{c}\text { Jumla } \\
\mathrm{h}\end{array}$} & Priority \\
\cline { 1 - 1 } $\begin{array}{c}\text { Pengetahu } \\
\text { an } \\
\text { Agi }\end{array}$ & Agi & David & Karta & Rizki & & Vactor \\
David & 0.47 & 0.55 & 0.33 & 0.41 & 1.77 & 0.44 \\
Karta & 0.24 & 0.28 & 0.42 & 0.36 & 1.29 & 0.32 \\
Rizki & 0.16 & 0.06 & 0.10 & 0.09 & 0.39 & 0.10 \\
Jumlah & 1.00 & 1.00 & 1.00 & 1.00 & 4.00 & 1.00
\end{tabular}

Sumber: Hasil Penelitian

Selanjutnya menghitung nilai konsistensi rasio dari matriks perbandingan kriteria Pengetahuan. Langkah-langkahnya sebagai berikut:

1. Mencari nilai $\mathrm{Cl}$ (Consistency Indeks)

Dalam mencari nilai $\mathrm{Cl}$ (Consistency Indeks) terlebih dahulu kita cari nilai lamda max, yang harus dilakukan adalah mengalikan setiap jumlah nilai kriteria pengetahuan dengan hasil setiap rata-rata (Priority Vactor) dari kriteria pengetahuan hasil yang diperoleh adalah:

$\lambda_{\text {Max }}=4.106$

Karena matriks terdiri dari 4 alternatif maka indeks konsistensi yang diperoleh sebagai berikut:

$\mathrm{Cl}=\frac{\lambda_{\max }-n}{n-1}=\frac{4.106-4}{4-1}=\frac{(0.106)}{3}=0.035$

2. Menentukan nilai RI

Matriks terdiri dari 4 alternatif maka nilai $\mathrm{RI}$ yang di dapat adalah 0.90

3. Menghitung CR (Consistency Rasio)

Jika $n=4, \mathrm{RI}=0.90$ maka:

$C R \frac{C I}{I R}=\frac{0.035}{0.9}=0.039$

Karena CR $<0.100$ maka preferensi responden adalah konsisten.

B. Perhitungan Alternatif Kriteria

Keterampilan

Tabel 6 Alternatif Kriteria Keterampilan

\begin{tabular}{lllll}
\hline $\begin{array}{l}\text { Keterampil } \\
\text { an }\end{array}$ & Agi & David & Karta & Rizki \\
\hline Agi & 1.00 & 0.79 & 0.28 & 0.44 \\
David & 1.26 & 1.00 & 0.37 & 0.40 \\
Karta & 3.63 & 2.71 & 1.00 & 2.29 \\
Rizki & 2.29 & 2.52 & 0.44 & 1.00 \\
Jumlah & 8.18 & 7.03 & 2.08 & 4.12 \\
\hline
\end{tabular}

Sumber: Hasil Penelitian

Selanjutnya setiap unsur-unsur pada tiap kolom dibagi dengan jumlah kolom yang bersangkutan maka akan diperoleh bobot alternatif yang dinormalkan. Kemudian dari masing-masing alternatif tersebut lalu di jumlahkan. Setelah didapat hasil dari penjumlahan maka selanjutnya adalah menentukan nilai rata-rata (Priority Vactor) dengan membagi hasil rata-rata dengan jumlah alternatif yakni 4. Maka diperoleh hasil sebagai berikut:

Tabel 7 Nilai Eigen Alternatif Kriteria Keterampilan

\begin{tabular}{cccccccc}
\hline & \multicolumn{3}{c}{ NILAI EIGEN } & \multicolumn{3}{c}{$\begin{array}{c}\text { Jumla } \\
\mathrm{h}\end{array}$} & Priority \\
\cline { 1 - 1 } $\begin{array}{c}\text { Keterampil } \\
\text { an } \\
\text { Agi }\end{array}$ & Agi & David & Karta & Rizki & & Vactor \\
David & 0.12 & 0.11 & 0.13 & 0.11 & 0.47 & 0.12 \\
Karta & 0.44 & 0.14 & 0.18 & 0.10 & 0.57 & 0.14 \\
Rizki & 0.28 & 0.36 & 0.21 & 0.24 & 1.09 & 0.27 \\
Jumlah & 1.00 & 1.00 & 1.00 & 1.00 & 4.00 & 1.00
\end{tabular}

Sumber: Hasil Penelitian

Selanjutnya menghitung nilai konsistensi rasio dari matriks perbandingan kriteria keterampilan. Langkah-langkahnya sebagai berikut:

1. Mencari nilai $\mathrm{Cl}$ (Consistency Indeks)

Dalam mencari nilai $\mathrm{Cl}$ (Consistency Indeks) terlebih dahulu kita cari nilai lamda max, yang harus dilakukan adalah mengalikan setiap jumlah nilai kriteria keterampilan dengan hasil setiap rata-rata (Priority Vactor) dari kriteria keterampilan hasil yang diperoleh adalah:

$\lambda_{\text {Max }}=4.064$

Karena matriks terdiri dari 4 alternatif maka indeks konsistensi yang diperoleh sebagai berikut:

$\mathrm{Cl}=\frac{\lambda_{\text {Max }}-n}{n-1}=\frac{4.064-4}{4-1}=\frac{(0.064)}{3}=0.021$

2. Menentukan nilai RI

Matriks terdiri dari 4 alternatif maka nilai RI yang di dapat adalah 0.90

3. Menghitung CR (Consistency Rasio) Jika $n=4, \mathrm{RI}=0.90$ maka:

$C R \frac{C I}{I R}=\frac{0.021}{0.9}=0.024$

Karena $\mathrm{CR}<0.100$ maka preferensi responden adalah konsisten.

C. Perhitungan Alternatif Kriteria Sikap Kerja

Tabel 8 Alternatif Kriteria Sikap Kerja

\begin{tabular}{lllll}
\hline Sikap Kerja & Agi & David & Karta & Rizki \\
\hline Agi & 1.00 & 2.88 & 2.00 & 2.62 \\
David & 0.35 & 1.00 & 0.79 & 1.44 \\
Karta & 0.50 & 1.26 & 1.00 & 2.29 \\
\hline
\end{tabular}




$\begin{array}{lllll}\text { Rizki } & 0.38 & 0.69 & 0.44 & 1.00 \\ \text { Jumlah } & 2.23 & 5.84 & 4.23 & 7.35\end{array}$

\section{Sumber: Hasil Penelitian}

Selanjutnya setiap unsur-unsur pada tiap kolom dibagi dengan jumlah kolom yang bersangkutan maka akan diperoleh bobot alternatif yang dinormalkan. Kemudian dari masing-masing alternatif tersebut lalu di jumlahkan. Setelah didapat hasil dari penjumlahan maka selanjutnya adalah menentukan nilai rata-rata (Priority Vactor) dengan membagi hasil rata-rata dengan jumlah alternatif yakni 4. Maka diperoleh hasil sebagai berikut:

Tabel 9 Nilai Eigen Alternatif Kriteria Sikap Kerja

\begin{tabular}{cccccccc}
\hline \multicolumn{3}{c}{ NILAI EIGEN } & & & $\begin{array}{c}\text { Jumla } \\
\mathrm{h}\end{array}$ & Priority \\
\cline { 1 - 1 } $\begin{array}{c}\text { Sikap } \\
\text { Kerja } \\
\text { Agi }\end{array}$ & Agi & David & Karta & Rizki & & Vactor \\
David & 0.45 & 0.49 & 0.47 & 0.36 & 1.77 & 0.44 \\
Karta & 0.16 & 0.17 & 0.19 & 0.20 & 0.71 & 0.18 \\
Rizki & 0.17 & 0.22 & 0.24 & 0.31 & 0.99 & 0.25 \\
Jumlah & 1.00 & 1.00 & 1.00 & 1.00 & 4.00 & 1.00
\end{tabular}

Sumber: Hasil Penelitian

Selanjutnya menghitung nilai konsistensi rasio dari matriks perbandingan kriteria sikap kerja. Langkah-langkahnya sebagai berikut:

1. Mencari nilai $\mathrm{Cl}$ (Consistency Indeks)

Dalam mencari nilai $\mathrm{Cl}$ (Consistency Indeks) terlebih dahulu kita cari nilai lamda max, yang harus dilakukan adalah mengalikan setiap jumlah nilai kriteria sikap kerja dengan hasil setiap rata-rata (Priority Vactor) dari kriteria sikap kerja hasil yang diperoleh adalah:

$\lambda_{\operatorname{Max}}=4.042$

Karena matriks terdiri dari 4 alternatif maka indeks konsistensi yang diperoleh sebagai berikut:

$\mathrm{Cl}=\frac{\lambda_{\operatorname{Max}}-n}{n-1}=\frac{4.042-4}{4-1}=\frac{(0.042)}{3}=0.014$

2. Menentukan nilai RI

Matriks terdiri dari 4 alternatif maka nilai RI yang di dapat adalah 0.90

3. Menghitung CR (Consistency Rasio)

Jika $n=4, \mathrm{RI}=0.90$ maka:

$C R \frac{C I}{I R}=\frac{0.014}{0.9}=0.016$

Karena CR $<0.100$ maka preferensi responden adalah konsisten.

D. Perhitungan Alternatif Kriteria Komunikasi
Tabel 10 Perhitungan Alternatif Kriteria Komunikasi

\begin{tabular}{ccccc}
\hline Komunikasi & Agi & David & Karta & Rizki \\
\hline Agi & 1.00 & 4.22 & 4.00 & 4.64 \\
David & 0.24 & 1.00 & 0.69 & 1.26 \\
Karta & 0.25 & 1.44 & 1.00 & 2.29 \\
Rizki & 0.22 & 0.79 & 0.44 & 1.00 \\
Jumlah & 1.70 & 7.45 & 6.13 & 9.19
\end{tabular}

Sumber: Hasil Penelitian

Selanjutnya setiap unsur-unsur pada tiap kolom dibagi dengan jumlah kolom yang bersangkutan maka akan diperoleh bobot alternatif yang dinormalkan. Kemudian dari masing-masing alternatif tersebut lalu di jumlahkan. Setelah didapat hasil dari penjumlahan maka selanjutnya adalah menentukan nilai rata-rata (Priority Vactor) dengan membagi hasil rata-rata dengan jumlah alternatif yakni 4. Maka diperoleh hasil sebagai berikut:

Tabel 11 Nilai Eigen Alternatif Kriteria Komunikasi

\begin{tabular}{|c|c|c|c|c|c|c|}
\hline \multicolumn{5}{|c|}{ NILAI EIGEN } & \multirow{2}{*}{$\underset{\mathrm{h}}{\text { Jumla }}$} & \multirow{2}{*}{$\begin{array}{l}\text { Priority } \\
\text { Vactor }\end{array}$} \\
\hline Komunikasi & Agi & David & Karta & Rizki & & \\
\hline Agi & $\begin{array}{c}0.5 \\
9\end{array}$ & 0.57 & 0.65 & 0.51 & 2.31 & 0.58 \\
\hline David & $\begin{array}{c}0.1 \\
4\end{array}$ & 0.13 & 0.11 & 0.14 & 0.52 & 0.13 \\
\hline Karta & $\begin{array}{c}0.1 \\
5\end{array}$ & 0.19 & 0.16 & 0.25 & 0.75 & 0.19 \\
\hline Rizki & $\begin{array}{c}0.1 \\
3\end{array}$ & 0.11 & 0.07 & 0.11 & 0.41 & 0.10 \\
\hline Jumlah & $\begin{array}{c}1.0 \\
0\end{array}$ & 1.00 & 1.00 & 1.00 & 4.00 & 1.00 \\
\hline
\end{tabular}

Sumber: Hasil Penelitian

Selanjutnya menghitung nilai konsistensi rasio dari matriks perbandingan kriteria komunikasi. Langkah-langkahnya sebagai berikut:

1. Mencari nilai $\mathrm{Cl}$ (Consistency Indeks)

Dalam mencari nilai $\mathrm{Cl}$ (Consistency

Indeks) terlebih dahulu kita cari nilai lamda

max, yang harus dilakukan adalah

mengalikan setiap jumlah nilai kriteria

komunikasi dengan hasil setiap rata-rata

(Priority Vactor) dari kriteria komunikasi

hasil yang diperoleh adalah:

$\lambda_{\text {Max }}=4.062$

Karena matriks terdiri dari 4 alternatif maka indeks konsistensi yang diperoleh sebagai berikut:

$\mathrm{Cl}=\frac{\lambda_{\operatorname{Max}}-n}{n-1}=\frac{4.062-4}{4-1}=\frac{(0.062)}{3}=0.021$

2. Menentukan nilai RI

Matriks terdiri dari 4 alternatif maka nilai RI yang di dapat adalah 0.90 
3. Menghitung CR (Consistency Rasio)

Jika $n=4, \mathrm{RI}=0.90$ maka:

$C R \frac{C I}{I R}=\frac{0.021}{0.9}=0.023$

Karena CR $<0.100$ maka preferensi responden adalah konsisten.

E. Perhitungan Alternatif Kriteria Kehadiran

Tabel 12 Perhitungan Alternatif Kriteria Kehadiran

\begin{tabular}{ccccc}
\hline Kehadiran & Agi & David & Karta & Rizki \\
\hline Agi & 1.00 & 0.50 & 0.38 & 2.00 \\
David & 2.00 & 1.00 & 0.44 & 2.29 \\
Karta & 2.62 & 2.29 & 1.00 & 3.91 \\
Rizki & 0.50 & 0.44 & 0.26 & 1.00 \\
Jumlah & 6.12 & 4.23 & 2.07 & 9.20
\end{tabular}

Sumber: Hasil Penelitian

Selanjutnya setiap unsur-unsur pada tiap kolom dibagi dengan jumlah kolom yang bersangkutan maka akan diperoleh bobot alternatif yang dinormalkan. Kemudian dari masing-masing alternatif tersebut lalu di jumlahkan. Setelah didapat hasil dari penjumlahan maka selanjutnya adalah menentukan nilai rata-rata (Priority Vactor) dengan membagi hasil rata-rata dengan jumlah alternatif yakni 4. Maka diperoleh hasil sebagai berikut:

Tabel 13 Nilai Eigen Alternatif Kriteria Kehadiran

\begin{tabular}{|c|c|c|c|c|c|c|}
\hline \multicolumn{5}{|c|}{ NILAI EIGEN } & \multirow{2}{*}{$\underset{\mathrm{h}}{\text { Jumla }}$} & \multirow{2}{*}{$\begin{array}{l}\text { Priority } \\
\text { Vactor }\end{array}$} \\
\hline $\begin{array}{c}\text { Kehadir } \\
\text { an }\end{array}$ & Agi & David & Karta & Rizki & & \\
\hline Agi & 0.16 & 0.12 & 0.18 & 0.22 & 0.68 & 0.17 \\
\hline David & 0.33 & 0.24 & 0.21 & 0.25 & 1.02 & 0.26 \\
\hline Karta & 0.43 & 0.54 & 0.48 & 0.43 & 1.88 & 0.47 \\
\hline Rizki & 0.08 & 0.10 & 0.12 & 0.11 & 0.42 & 0.10 \\
\hline Jumlah & 1.00 & 1.00 & 1.00 & 1.00 & 4.00 & 1.00 \\
\hline
\end{tabular}

Sumber: Hasil Penelitian

Selanjutnya menghitung nilai konsistensi rasio dari matriks perbandingan kriteria kehadiran. Langkah-langkahnya sebagai berikut:

1. Mencari nilai $\mathrm{Cl}$ (Consistency Indeks)

Dalam mencari nilai $\mathrm{Cl}$ (Consistency Indeks) terlebih dahulu kita cari nilai lamda max, yang harus dilakukan adalah mengalikan setiap jumlah nilai kriteria kehadiran dengan hasil setiap rata-rata (Priority Vactor) dari kriteria kehadiran hasil yang diperoleh adalah:

$\lambda_{\text {Max }}=4.058$
Karena matriks terdiri dari 4 alternatif maka indeks konsistensi yang diperoleh sebagai berikut:

$$
\mathrm{Cl}=\frac{\lambda_{\operatorname{Max}}-n}{n-1}=\frac{4.058-4}{4-1}=\frac{(0.058)}{3}=0.019
$$

2. Menentukan nilai RI

Matriks terdiri dari 4 alternatif maka nilai RI yang di dapat adalah 0.90

3. Menghitung CR (Consistency Rasio)

Jika $n=4, \mathrm{RI}=0.90$ maka:

$C R \frac{C I}{I R}=\frac{0.019}{0.9}=0.022$

Karena CR $<0.100$ maka preferensi responden adalah konsisten.

F. Perhitungan Alternatif Kriteria Kerja sama

Tabel 14 Perhitungan Alternatif Kriteria Kerja sama

\begin{tabular}{ccccc}
\hline Kerjasama & Agi & David & Karta & Rizki \\
\hline Agi & 1.00 & 3.00 & 0.91 & 1.26 \\
David & 0.33 & 1.00 & 0.44 & 0.40 \\
Karta & 1.10 & 2.29 & 1.00 & 1.59 \\
Rizki & 0.79 & 2.52 & 0.63 & 1.00 \\
Jumlah & 3.23 & 8.81 & 2.98 & 4.24
\end{tabular}

Sumber: Hasil Penelitian

Selanjutnya setiap unsur-unsur pada tiap kolom dibagi dengan jumlah kolom yang bersangkutan maka akan diperoleh bobot alternatif yang dinormalkan. Kemudian dari masing-masing alternatif tersebut lalu di jumlahkan. Setelah didapat hasil dari penjumlahan maka selanjutnya adalah menentukan nilai rata-rata (Priority Vactor) dengan membagi hasil rata-rata dengan jumlah alternatif yakni 4. Maka diperoleh hasil sebagai berikut:

Tabel 15 Nilai Eigen Alternatif Kriteria Kerjasama

\begin{tabular}{|c|c|c|c|c|c|c|}
\hline \multicolumn{5}{|c|}{ NILAI EIGEN } & \multirow{2}{*}{$\begin{array}{c}\text { Jumla } \\
\mathrm{h}\end{array}$} & \multirow{2}{*}{$\begin{array}{l}\text { Priority } \\
\text { Vactor }\end{array}$} \\
\hline $\begin{array}{c}\text { Kerjasam } \\
\text { a }\end{array}$ & Agi & David & Karta & Rizki & & \\
\hline Agi & 0.31 & 0.34 & 0.31 & 0.30 & 1.25 & 0.31 \\
\hline David & 0.10 & 0.11 & 0.15 & 0.09 & 0.46 & 0.11 \\
\hline Karta & 0.34 & 0.26 & 0.34 & 0.37 & 1.31 & 0.33 \\
\hline Rizki & 0.25 & 0.29 & 0.21 & 0.24 & 0.98 & 0.24 \\
\hline Jumlah & 1.00 & 1.00 & 1.00 & 1.00 & 4.00 & 1.00 \\
\hline
\end{tabular}

Sumber: Hasil Penelitian

Selanjutnya menghitung nilai konsistensi rasio dari matriks perbandingan kriteria Kerja Sama. Langkah-langkahnya sebagai berikut: 1. Mencari nilai $\mathrm{Cl}$ (Consistency Indeks) 
Dalam mencari nilai $\mathrm{Cl}$ (Consistency Indeks) terlebih dahulu kita cari nilai lamda max, yang harus dilakukan adalah mengalikan setiap jumlah nilai kriteria kerja sama dengan hasil setiap rata-rata (Priority Vactor) dari kriteria kerja sama hasil yang diperoleh adalah:

$\lambda_{\text {Max }}=4.032$

Karena matriks terdiri dari 4 alternatif maka indeks konsistensi yang diperoleh sebagai berikut:

$\mathrm{Cl}=\frac{\lambda_{\operatorname{Max}}-n}{n-1}=\frac{4.032-4}{4-1}=\frac{(0.032)}{3}=0.011$

2. Menentukan nilai RI

Matriks terdiri dari 4 alternatif maka nilai RI yang di dapat adalah 0.90

3. Menghitung $\mathrm{CR}$ (Consistency Rasio)

Jika $n=4, \mathrm{RI}=0.90$ maka:

$C R \frac{C I}{I R}=\frac{0.011}{0.9}=0.012$

Karena CR $<0.100$ maka preferensi responden adalah konsisten.

Selanjutnya perhitungan total rangking. yang harus dilakukan adalah dengan mengalikan rata-rata dari kriteria utama dengan rata-rata dari alternatif maka hasil yang didapat sebagai berikut:

Tabel 16 Perangkingan

\begin{tabular}{lcc}
\hline \multicolumn{1}{c}{ Nama } & Hasil & Peringkat \\
\hline Karta Atmaja & 0.344 & 1 \\
Agi Suci Nur Indra & 0.295 & 2 \\
John David Sitohang & 0.201 & 3 \\
Rizki Abdullah & 0.160 & 4 \\
\hline
\end{tabular}

Sumber: Hasil Penelitian

Hasil Implementasi dengan aplikasi Expert Choice Versi 11

Urutan prioritas dalam penentuan karyawan tetap menggunakan aplikasi Expert Choice Versi 11 dapat dilihat pada gambar berikut:

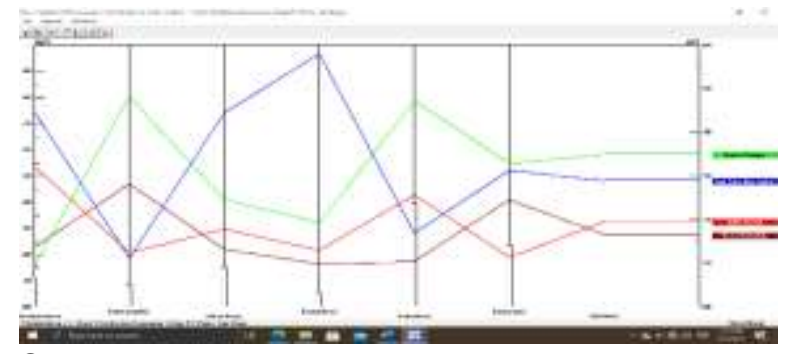

Sumber: Hasil Penelitian

Gambar 2. Grafik Perfomance
Berikut adalah hasil perhitungan menggunakan aplikasi Expert Choice pada grafik Dynamic

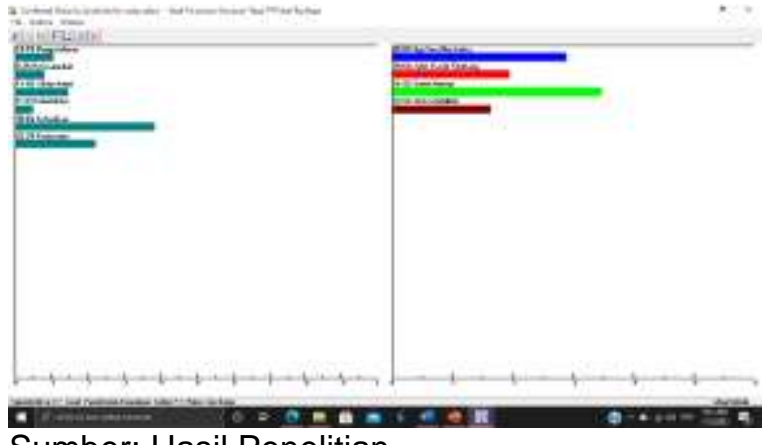

Sumber: Hasil Penelitian

Gambar 3. Grafik Dynamic

Berdasarkan pada gambar 3 kriteria kehadiran lebih penting dalam penentuan perekrutan karyawan tetap di PT. Prima Top Boga dengan presentase $38.8 \%$ selanjutnya kriteria kerjasama memperoleh $22.3 \%$ kriteria sikap kerja $14.8 \%$ kriteria pengetahuan $10.7 \%$ kriteria keterampilan $8.2 \%$ dan kriteria komunikasi mendapat presentase terakhir sebanyak $5.1 \%$. Selanjutnya untuk kandidat calon karyawan tetap pada peringkat pertama adalah Karta Atmaja dengan perolehan minat responden $34.9 \%$. Pada peringkat kedua Agi Suci Nur Indra dengan perolehan presentase sebanyak $29.0 \%$. Pada peringkat ketiga John David Sitohang sebesar $19.6 \%$ dan yang terakhir Rizki Abdullah 16.5\%

\section{Kesimpulan}

Setelah dilakukannya berbagai tahapan penelitian, penulis mendapat kesimpulan dalam proses perekrutan karyawan tetap pada PT Prima Top Boga. Adapun kesimpulannya adalah kriteria yang diberikan peneliti sangat berpengaruh dalam keputusan pemilihan karyawan tetap pada PT. Prima Top Boga hal ini bisa diketahui dari hasil preferensi ke 4 calon karyawan tetap. Pada peringkat pertama yaitu Karta Atmaja dengan perolehan hasil preferensi sebanyak 0.344 disusul Agi Suci Nur Indra di peringkat kedua dengan hasil preferensi sebanyak 0.295. Sedangkan John David Sitohang berada di peringkat ketiga dengan hasil preferensi sebanyak 0.201 dan Rizki Abdullah berada di peringkat terakhir dengan perolehan preferensi sebanyak 0.160. Dari hasil perhitungan Analitycal Hierarchy Process (AHP) maka dapat diputuskan bahwa Karta Atmaja telah lolos menjadi karyawan tetap pada PT Prima Top Boga. Metode Analitycal Hierarchy Process (AHP) sangat cocok digunakan dalam pengambilan keputusan dalam segala bidang pemilihan. 


\section{Referensi}

Agustini, F., \& Ariska, E. R. (2019). Penerapan Metode Simple Additive Weighting (Saw) Dengan Model Fuzzy Model Attribute Decision Making (Fmadm) Penilaian Kinerja Karyawan Dtpeduli bekasi. Jurnal Techno Nusa Mandiri, 16(1), 21-28. https://doi.org/10.33480/techno.v16i1.107

Budihartanti, C., Dewi, Y. N., \& Purnamasari, I. (2020). Sistem Pendukung Keputusan Seleksi Penerimaan Karyawan Baru Menggunakan Metode Weighted Product (WP). Jisamar, 4(4), 71-77.

Diana. (2018). Metode dan Aplikasi Sistem Pendukung Keputusan (1st ed.). DEEPUBLISH.

Fauzi, A., Indriyani, N., Bayu, A., \& Yanto, H. (2020). Sistem Pendukung Keputusan Pengangkatan Karyawan Tetap Menggunakan Metode Analytic Hierachy Process keputusan yang cukup sederhana dan dapat menjadi salah satu alternatif dalam mengambil. Teknologi Informatika Dan Komputer MH Thamrin, $6(1), 1-8$.

Hertyana, H. (2019). Sistem Pendukung Keputusan Seleksi Pemilihan Perguruan Tinggi Menggunakan Metode Topsis. Jurnal Pilar Nusa Mandiri, 15(1), 97-102. https://doi.org/10.33480/pilar.v15i1.223

Iriadi, N., \& Yohana, D. (2016). Pengaruh Sistem Pendukung Keputusan Dalam Pemilihan Mobil LCGC Dengan Metode Analytic Hierarchy Process (AHP). Jurnal Khatulistiwa Informatika, IV, 173-182. https://doi.org/10.15421/nvlvet7002

Mahmudi, Kusrini, \& Henderi. (2019). Penerapan Metode AHP dan Electre Dalam Proses Seleksi Karyawan Pada PT. Gawih Jaya Banjarmasin. TEKNOMATIKA, Vol. 11, 152-164.

Marsono. (2020). Penggunaan Metode Analytical Hierarchy Process (AHP) Dalam Penelitian (1st ed.). IN Media.

Narti. (2017). Sistem Pendukung Keputusan Pemilihan Siswa Berprestasi Menggunakan Metode AHP Dan Topsis. Jurnal Informatika, 4(2), 196-205.

Narti, N.-, Sriyadi, S., Rahmayani, N., \& Syarif, M. (2019). Pengambilan Keputusan Memilih Sekolah Dengan Metode AHP. Jurnal Informatika, 6(1), 143-150. https://doi.org/10.31311/ji.v6i1.5552

Nofriansyah, D., \& Defit, S. (2017). Multi Criteria Decision Making (MCDM) Pada Sistem Pendukung Keputusan (1st ed.). DEEPUBLISH.

PHS, Y. P., \& Destiana, S. (2020). Sistem Pendukung Keputusan Pemilihan Santri Baru Teras Tahfidz di Teras Dakwah
Menggunakan Metode Topsis. FAHMA, 4(3), $57-71$ http://marefateadyan.nashriyat.ir/node/ 15 0

Pratiwi, A. A. G., Septiana, L., \& Spriadi, I. (2018). Penerapan Metode Fuzzy Simple Additive Weighting (SAW) Untuk Pengangkatan Karyawan Kontrak Pada PT. Aranad Karya Saranatama. Inti Nusa Mandiri, 13(1), 1-8.

Putri, P. K., \& Mahendra, I. (2019). Implementasi Metode Analytical Hierarchy Process ( Ahp ) Dalam Sistem Pendukung Keputusan Pembelian Rumah Di Kota Tangerang. Jurnal Teknoinfo, 13(1), 3738.

https://ejurnal.teknokrat.ac.id/index.php/t eknoinfo/article/view/238/157

Saputra, D. A., \& Sudrajat, E. (2020). Sistem Pendukung Keputusan Pemilihan JurusanMenggunakan Metode Analytical Hierarchy Process ( AHP ) Studi Kasus: SMK Muhammadiyah Bumiayu. Jurnal Sistem Informasi Dan Teknologi Peradaban (JSITP), 1(1), 18-23.

Sasongko, A., Astuti, I. F., \& Maharani, S. (2017). Pemilihan Karyawan Baru Dengan Metode Ahp (Analytic Hierarchy Process).

Supriyadi, Ginting, G., \& Bu'ulolo, E. (2019). Fuzzy Multiple Attribute Decision Macking ( FMADM ) Berdasarkan Metode Oreste Untuk Menentukan Lokasi Promosi ( Studi Kasus: STMIK Budi Darma Medan ). Jurnal Pelita Informatika, 8, 292-297.

Umar, R., Fadlil, A., \& Yuminah, Y. (2018). Sistem Pendukung Keputusan dengan Metode AHP untuk Penilaian Kompetensi Soft Skill Karyawan. Khazanah Informatika: Jurnal IImu Komputer Dan Informatika, 4(1), 27. https://doi.org/10.23917/khif.v4i1.5978 